\title{
Fertilizer effect on some basil bioactive compounds and yield
}

\section{Efeito de fertilizantes em alguns compostos bioativos e produção de manjericão}

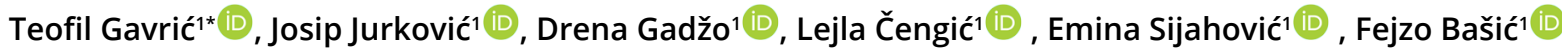

'University of Sarajevo, Faculty of Agriculture and Food Sciences, Sarajevo, Bosnia and Herzegovina

${ }^{*}$ Corresponding author: t.gavric@ppf.unsa.ba

Received in February 19, 2021 and approved in June 9, 2021

\begin{abstract}
Basil (Ocimum basilicum L.) is an annual plant that belongs to the Lamiaceae family. It is used as an aromatic and medicinal plant. Basil is grown in different regions with varying climates; the productivity and quality are influenced by both abiotic and biotic factors. This study was aimed to determine the impact of the application of different types of fertilizers on the yield and contents of some bioactive components in basil. The treatments consisted of three different types of fertilizers (mineral, organomineral, and organic) and control (without fertilization). The yield per plant and the essential oil content with fertilizer treatment were better than that in control. The highest fresh yield (450.9 g per plant) and oil content $\left(0.94 \mathrm{~mL} 100 \mathrm{~g}^{-1}\right)$ were recorded in basil cultivated using mineral fertilizers. Furthermore, the fresh yield ( 333.9 and $327.8 \mathrm{~g}$ per plant) and oil content $\left(0.87\right.$ and $\left.0.85 \mathrm{~mL} 100 \mathrm{~g}^{-1}\right)$ were higher after the application of organic and organomineral fertilizers compared to that in the control treatment. There was no significant effect of fertilizer application on the total phenolics, total flavonoids, and antioxidant capacity. This study demonstrated a suitable practical application of organomineral fertilizers as a nutrient source in basil crop production in areas where the use of mineral and organic fertilizers is limited.
\end{abstract}

Index terms: Ocimum basilicum L.; essential oil; antioxidant activity.

\begin{abstract}
RESUMO
O Manjericão (Ocimum basilicum L.) é uma planta anual pertencente à família Lamiaceae. É usada como planta aromática e medicinal. O manjericão é cultivado em diferentes regiões com climas variados; a produtividade e a qualidade são influenciadas por fatores abióticos e bióticos. Este estudo teve como objetivo determinar o impacto da aplicação de diferentes tipos de fertilizantes na produção e conteúdo de alguns componentes bioativos de manjericão. Os tratamentos consistiram em três tipos diferentes de fertilizantes (minerais, organominerais e orgânicos) e controle (sem fertilização). O rendimento por planta e o teor de óleo essencial com tratamento de fertilizantes foram melhores do que o controle. O maior rendimento fresco $(450,9 \mathrm{~g}$ por planta) e teor de óleo $(0,94 \mathrm{~mL} 100 \mathrm{~g}$-1) foram registrados em manjericão cultivado com o uso de fertilizantes minerais. Além disso, o rendimento fresco (333,9 e 327,8 g por planta) e teor de óleo $\left(0,87\right.$ e $\left.0,85 \mathrm{~mL} 100 \mathrm{~g}^{-1}\right)$ foram maiores após a aplicação de fertilizantes orgânicos e organominerais em comparação com o do tratamento controle. Não houve efeito significativo da aplicação de fertilizantes em fenólicos totais, flavonóides totais e capacidade antioxidante. Este estudo demonstrou uma aplicação prática adequada de fertilizantes organominerais como fonte de nutrientes na produção de manjericão em áreas onde o uso de fertilizantes minerais e orgânicos é limitado.
\end{abstract}

Termos para indexação: Ocimum basilicum L.; óleo essencial; atividade antioxidante.

\section{INTRODUCTION}

Basil (Ocimum basilicum L.) is an annual plant and belongs to the Lamiaceae family. It is native to Asia, particularly to India, but is cultivated worldwide (Bucktowar; Bucktowar; Devi Bholoa, 2016). Basil is particularly popular in households where it is most often used as a spice plant. It is also used in pharmaceuticals, cosmetics, the food industries, aromatherapy, and traditional and homeopathic medicines (Bucktowar; Bucktowar; Devi Bholoa, 2016; Kasote et al., 2015; Stanojković-Sebić et al., 2017).
The pharmacological properties of medicinal and aromatic plants depend on various bioactive phytochemical compounds that have specific physiological effects in humans (Zareen et al., 2014). Some of the bioactive compounds are phenols, flavonoids, alkaloids, and tannins. The content of these components in the plant mainly depends on the species (Gavrić et al., 2018a). However, many abiotic factors, including drought, UV radiation, salinity, pesticides, altitude, location of growing, weather conditions, etc., have a significant effect on the production of bioactive components (Del Valle et al., 2020; 
Shahrajabian; Wenli Sun; Cheng, 2020; Portilla et al., 2020; Sharma et al., 2019; Tsasi et al., 2017). On the other hand, various cultural practices directly cause changes to the environment, which further lead to changes in the yield and quality of plants. One of the main cultural practices that play an important role in the growth, development and yield is the application of fertilizers (Dzida et al., 2018).

It is well known that fertilizers are applied to cultivate medicinal and aromatic plants, including basil. Fertilizers have a positive effect on the fresh and dry herb yield and essential oil content (Ipsilandis et al., 2020; Lima et al., 2020). However, fertilizers can have positive and negative impacts on phenolic compounds in plants (Amarowicz et al., 2020; Portilla et al., 2020; Teliban et al., 2020). According to Kazimierczak et al. (2021), the phenol content in plants depends on the type of fertilizer applied. Two different kinds of fertilizers are often used in the cultivation of medicinal and aromatic plants, organic and mineral fertilizers.

Organic fertilizers are mostly recommended for the cultivation of medicinal plants (Sodré et al., 2011). These contain all the micro and macronutrients essential for plants and have a positive effect on microorganisms, the structure of the soil, and soil water availability (Hirzel et al., 2018). However, the main shortcomings of organic fertilizers are that they are low in nutrient content and have slow decomposition compared to mineral fertilizers; additionally, the sources of organic fertilizers are also limited (Han et al., 2016; Timsina, 2018).

Due to these shortcomings, and also due to the lack of organic fertilizers, mineral fertilizers are used in the cultivation of medicinal plants in some areas. They are cheap and contain substantially higher amounts of macronutrients that are readily available to plants (Timsina, 2018). However, the use of mineral fertilizers in high doses results in problems such as nutrient loss, soil acidification, surface water contamination, and reduction in soil microorganisms (Han et al., 2016). Thus, both mineral and organic fertilizers have some advantages and shortcomings. In recent years, to overcome the shortcomings of these fertilizers, organomineral fertilizers are being used. These fertilizers are also used in the production of medicinal plants. Organomineral fertilizers have the combined benefits of mineral and organic fertilizers (Ojo; Olowoake; Obembe, 2014). Research by some authors (Corrêa et al., 2016; Deeks et al., 2013; Silva et al., 2017) has shown that some crops have a positive reaction after the application of organomineral fertilizers.

Since applying mineral fertilizers frequently can cause disturbances in the soil, and as there are not enough organic fertilizers, one alternative would be to use organomineral fertilizers. However, research on growing basil using organomineral fertilizers has yet to be performed under the agro-ecological conditions of Bosnia and Herzegovina. In this context, our hypothesis is that the yield and fresh mass of basil grown using organomineral fertilizers will be similar to that grown by using organic and mineral fertilize. Therefore, the objective was to evaluate the yield and content of some bioactive components of basil grown by applying different types of fertilizers.

\section{MATERIAL AND METHODS}

Field experiment. A field experiment was conducted at a private farm in Kakanj, Bosnia and Herzegovina (the coordinates of the study site were: latitude $43^{\circ} 49^{\prime} 34.42^{\prime \prime} \mathrm{N}$, longitude $18^{\circ} 19^{\prime} 18.48^{\prime \prime} \mathrm{E}$; at an altitude of $505 \mathrm{~m}$ ). The experiment was set up during the growing season of 2019. A variety of basil called "Genovese" was used for this study. Basil seedlings for transplanting were grown in a greenhouse. Seedlings were raised in polystyrene containers using a commercial substrate "Klasmann Potgrond H". Each tray contained 104 cells (pots), and each cell had a capacity of $32 \mathrm{~mL}$. The basil seedlings were transplanted into the open field on the $25^{\text {th }}$ of May 2019, 50 days after being sown. Basil seedlings were planted at $50 \mathrm{~cm} \times 30 \mathrm{~cm}$ plant density. The size of each plot was $5.0 \mathrm{~m}^{2}(2.5 \mathrm{~m}$ long and 2.0 m wide).

Experimental design. The treatments of the experiment comprised a combination of different fertilizers, which were as follows: Mineral fertilizer NPK 7:20:30; organic fertilizer; organomineral fertilizer; and control (without fertilizer).

The mineral fertilizer was applied in a dose of $250 \mathrm{~kg} \mathrm{ha}^{-1}$. The organomineral fertilizer (manure) was applied in a dose of $10 \mathrm{t} \mathrm{ha}^{-1}$. Humus 20 Goldfert, which is an organomineral fertilizer, was applied in a dose of $250 \mathrm{~kg} \mathrm{ha}^{-1}$. The fertilizers were applied to the soil during ploughing seven days before the basil was transplanted.

\section{Chemical properties of fertilizers}

The mineral fertilizer NPK 7:20:30 was produced by INA Kutina, Croatia. It was composed of N (7\%), $\mathrm{P}_{2} \mathrm{O}_{5}(20 \%)$, and $\mathrm{K}_{2} \mathrm{O}(30 \%)$. The manure had a $\mathrm{pH}$ of 7.5 and consisted of organic matter $(20.66 \%), \mathrm{P}_{2} \mathrm{O}_{5}$ $(0.18 \%)$, and $\mathrm{K}_{2} \mathrm{O}(0.6 \%)$. The organomineral fertilizer (Humus 20 Goldfert) was produced by Candem Tarimsal 
Urunleri, Turkey. The fertilizer consisted of organic matter $(20 \%), \mathrm{N}(10 \%), \mathrm{P}_{2} \mathrm{O}_{5}(10.0 \%), \mathrm{K}_{2} \mathrm{O}(10.0 \%)$, and $\mathrm{SO}_{3}(15 \%)$.

Soil analysis. Soil sampling was conducted before the experiment was set up. After preparing a sample, the $\mathrm{pH}$ of the soil was determined by a digital $\mathrm{pH}$ meter (International Organization for Standardization - ISO $10390,1994)$, the humus content was measured by the dichromate method (ISO 14235, 1998), and the available $\mathrm{K}$ and $\mathrm{P}$ were evaluated by the $\mathrm{Al}$ method (Egnér; Riehm; Domingo, 1960).

According to the soil analysis, the experimental plot had the following chemical characteristics: $\mathrm{pH} 7.6$, $6.38 \%$ organic matter, $15.6 \mathrm{mg} / 100 \mathrm{~g} \mathrm{P}_{2} \mathrm{O}_{5}$ and 38.0 $\mathrm{mg} / 100 \mathrm{~g} \mathrm{~K}_{2} \mathrm{O}$.

Harvesting (cutting). Harvesting was performed twice during the beginning of flowering. The first cut was made on July 31,2019 . After the first cut, the aboveground mass of basil regenerated and redeveloped, after which, the basil began to reflower. The second cut was made on September 30, 2019

The yield of fresh and dry mass. The yield of fresh mass was calculated for 10 randomly selected plants per plot during the harvest. After harvest, the fresh basil samples were dried in a dark room at room temperature for 20 days. After drying, the dry mass yield was determined.

Determination of total essential oil. The content of essential oil in basil was measured using the Clevengertype apparatus (Clevenger, 1928). Briefly, $20 \mathrm{~g}$ of the powdered basil (dry mass) and $400 \mathrm{~mL}$ of distilled water were added to a flask. After hydrodistillation for $180 \mathrm{~min}$, the volume of the essential oils was measured.

Preparation of Extract. To prepare the extract, 0.5 $\mathrm{g}$ of dried plant material was placed in a $50 \mathrm{~mL}$ volumetric flask. The volume of the flask was made up to the mark with $60 \%$ ethanol. After cold extraction, the entire mixture was filtered and used for analysis.

Determination of total phenolic content. The total phenol content of the basil samples was determined by the modified Folin-Ciocalteu method (Gavrić et al., 2020). Briefly, $0.5 \mathrm{~mL}$ of each extract, blank or standard, was added to a $5 \mathrm{~mL}$ volumetric flask. Additionally, $0.25 \mathrm{~mL}$ Folin-Ciocalteu reagent was added to the flask, and the mixture was allowed to react. After $3 \mathrm{~min}, 0.75 \mathrm{~mL}$ of a $20 \%$ solution of $\mathrm{Na}_{2} \mathrm{CO}_{3}$ was added and the volume of the flask was made up to the mark with distilled water. The solution was incubated at room temperature for $120 \mathrm{~min}$ before measuring the absorbance at 765 $\mathrm{nm}$ in a spectrophotometer (Ultrospec 2100 Pro). The total phenol content was expressed as mg gallic acid equivalents (GAE).

Determination of total flavonoid content. The total flavonoid content of the basil samples was measured using the modified spectrophotometric method (Gavrić et al., 2018b). Initially, $0.5 \mathrm{~mL}$ of ethanol extract, blank or standard, was added to a $5 \mathrm{~mL}$ volumetric flask containing $2 \mathrm{~mL}$ of distilled water. To the flask, 0.15 $\mathrm{mL}$ of $5 \% \mathrm{NaNO}_{2}$ was added. After $6 \mathrm{~min}, 0.15 \mathrm{~mL} \mathrm{10 \%}$ $\mathrm{AlCl}_{3}$ and $1 \mathrm{~mL} 1 \mathrm{M} \mathrm{NaOH}$ were added. The total volume was made up to $5 \mathrm{~mL}$ with distilled water. The solution was mixed, and the absorbance was measured at 510 $\mathrm{nm}$. The total flavonoid content was calculated from the calibration curve obtained with $(+)$-catechin which was used as a standard.

Determination of antioxidant activity. The total antioxidant capacity of the basil extract was measured using the FRAP (ferric reducing antioxidant power) method (Benzie; Strain, 1996). Briefly, $240 \mu \mathrm{L}$ distilled water, $80 \mu \mathrm{L}$ basil extract, and $2.080 \mu \mathrm{L}$ FRAP reagent $\left(0.3 \mathrm{M}\right.$ acetate buffer: $20 \mathrm{mM} \mathrm{FeCl}_{3} \cdot 6 \mathrm{H}_{2} \mathrm{O}: 10$ $\mathrm{mM} \mathrm{TPTZ}=10: 1: 1)$ were added to an Erlenmeyer flask. The absorbance at $595 \mathrm{~nm}$ was measured after a 5 min incubation at $37^{\circ} \mathrm{C}$. The total capacity of the antioxidants was calculated from a calibration curve obtained by using an aqueous solution of $\mathrm{FeSO}_{4} 7 \mathrm{H}_{2} \mathrm{O}$ as a standard.

Meteorological data. Weather analysis was performed based on the data of a meteorological station in Zenica, Bosnia and Herzegovina, located at a $20 \mathrm{~km}$ air distance from the field site where the experiment was conducted (Federalni hidrometeorološki zavod - FHMZ, 2019).

\section{Statistical analysis}

In this experiment, two factors were considered, fertilization (three types) and cutting (harvesting; two times). The experiment was set up in a randomized block design and was replicated four times. The statistical analyses were performed in the SPSS 22.0 software programme (IBM, Armonk, New York, USA). All data were statistically analysed by ANOVA, and the level of significance was considered at $p<0.05$. The means of the variance were detected by Tukey's multi-comparison test and statistically significant differences were considered at $\mathrm{p}<0.05$. Pearson's correlation coefficients of fresh mass yield, dry mass yield, essential oil content, total phenolic content, total flavonoid content, and antioxidant capacity were also measured using SPSS 22.0. 


\section{RESULTS AND DISCUSSION}

The data in Table 1 shows that during the research period, the average temperature fluctuated from $17.4{ }^{\circ} \mathrm{C}$ (September) to $23.0^{\circ} \mathrm{C}$ (June). Temperatures above $20^{\circ} \mathrm{C}$ were recorded before the first cutting (June and July), while temperatures below $20{ }^{\circ} \mathrm{C}$ were recorded in September $\left(17.4{ }^{\circ} \mathrm{C}\right)$, a month before the second cutting. The amount of precipitation was unevenly distributed during the research period. The largest amount was recorded in the period up to the first cutting $(143.7 \mathrm{~mm}$ and $88.8 \mathrm{~mm}$ ), whereas the period between the first and the second cutting recorded significantly lesser precipitation (40.2 $\mathrm{mm}$ and $31.7 \mathrm{~mm}$ ).

The data presented in Table 2 shows that fresh and dry mass were significantly affected by the application of the different fertilizers. The highest yield (fresh and dry) was recorded in basil cultivated using the mineral fertilizer (450.9 and $98.0 \mathrm{~g}$, respectively) compared to that with the other fertilizer treatments. Therefore, the treatment with mineral fertilizer remained statistically on par with the treatments using the organic and organomineral fertilizers but recorded a significantly higher yield than that in the control treatment. Additionally, significantly higher fresh and dry yields were obtained by the application of organic and organomineral fertilizers, compared to the yield in control. The yields of fresh and dry mass were significantly dependent on the time of cutting and were significantly higher in the first cut (195.98 and $44.78 \mathrm{~g}$, respectively) than in the second cut (131.43 and 31.27, respectively).

Table 1: Average monthly air temperature and amount of precipitation for 2019 (FHMZ 2019).

\begin{tabular}{ccccccccccccc}
\hline & \multicolumn{10}{c}{ Month } \\
\hline & $\mathrm{I}$ & $\mathrm{II}$ & $\mathrm{III}$ & $\mathrm{IV}$ & $\mathrm{V}$ & $\mathrm{VI}$ & $\mathrm{VII}$ & $\mathrm{VIII}$ & $\mathrm{IX}$ & $\mathrm{X}$ & $\mathrm{XI}$ & $\mathrm{XII}$ \\
\hline $\begin{array}{c}\text { Average monthly air } \\
\text { temperature }\left({ }^{\circ} \mathrm{C}\right)\end{array}$ & -0.6 & 3.9 & 8.6 & 12.4 & 14.0 & 22.4 & 21.8 & 23.0 & 17.4 & 12.9 & 10.6 & 3.5 \\
$\begin{array}{c}\text { Amount of } \\
\text { precipitation (mm) }\end{array}$ & 60.8 & 78.8 & 47.5 & 99.8 & 90.9 & 143.7 & 88.8 & 40.2 & 31.7 & 38.0 & 80.3 & 64.8 \\
\hline
\end{tabular}

Table 2: The yield of fresh and dry mass.

\begin{tabular}{cccc}
\hline Cuts & Fertilizer & $\begin{array}{c}\text { Fresh mass yield } \\
\text { (g per plant) }\end{array}$ & $\begin{array}{c}\text { Dry mass yield } \\
\text { (g per plant) }\end{array}$ \\
\hline \multirow{3}{*}{ First cut } & Mineral & $259.40^{\mathrm{a}}$ & $57.25^{\mathrm{a}}$ \\
& Organic & $190.90^{\mathrm{ab}}$ & $46.80^{\mathrm{ab}}$ \\
& Organo-mineral & $200.13^{\mathrm{ab}}$ & $42.07^{\mathrm{ab}}$ \\
& Control & $133.50^{\mathrm{b}}$ & $33.00^{\mathrm{b}}$ \\
& Average & $195.98^{\mathrm{a}}$ & $44.78^{\mathrm{a}}$ \\
\hline \multirow{3}{*}{ Second cut } & Mineral & $191.50^{\mathrm{a}}$ & $40.75^{\mathrm{a}}$ \\
& Organic & $143.00^{\mathrm{a}}$ & $31.10^{\mathrm{b}}$ \\
& Organo-mineral & $127.71^{\mathrm{ab}}$ & $26.13^{\mathrm{b}}$ \\
& Control & $63.50^{\mathrm{b}}$ & $27.10^{\mathrm{b}}$ \\
& Average & $131.43^{\mathrm{b}}$ & $31.27^{\mathrm{b}}$ \\
\hline \multirow{3}{*}{ Total } & Mineral & 450.90 & 98.00 \\
& Organic & 333.90 & 77.90 \\
& Organo-mineral & 327.84 & 68.20 \\
& Control & 197.00 & 60.10 \\
& Average & 327.41 & 76.05 \\
\hline
\end{tabular}

${ }^{a}$ and ${ }^{b}$-Statistically significant difference at the 0.05 level.

ns-Statistically not significant difference at the 0.05 level. 
The application of mineral fertilizers provided a higher yield than that in the control treatment and treatments involving other types of fertilizers during both the cuts. The results of this study confirmed the findings of Teliban et al. (2020), where it was reported that mineral fertilizers stimulated the increase in basil biomass; there was an increase in the yield with mineral fertilizers compared to that with the control and the organic fertilizer set-ups. In our experiments, organic and organomineral fertilizers had a smaller effect on the yield compared to that with mineral fertilizers. This was because those fertilizers released nutrients slower than mineral fertilizers. The shortcomings of organic fertilizers are that they have low nutrient content (Han et al., 2016) and they decompose slowly, thus increasing the yield only slightly (Scagel; Lee, 2012). The yield of fresh and dry mass in the first cut was higher than that in the second cut. This was similar to the results of Corrado et al. (2020), where the researchers noted a significantly higher yield in the first cut compared to that in the second cut. They found that after the first cut, basil produced a higher number of smaller leaves, and thus, had lower yields. A similar conclusion was drawn by Gavrić et al. (2018b), where a 64\% higher yield was recorded in the first cut (283.16 $\mathrm{g}$ of fresh mass) compared to that in the second cut (182.3 $\mathrm{g}$ of fresh mass). They inferred that a reduction in yield was due to the air temperature, which was below the optimum level for the development of basil. Basil is a thermophilic plant from the tropics, which grows and develops optimally only if the temperatures are high enough during the entire growing period (Majkowska-Gadomska et al., 2017). During our experiments, a short cold period was recorded one month before the second cut, which was the main reason for lower yields of fresh and dry mass. Some researchers (Hassanain; Abdella, 2003; Hassan et al., 2015) have shown that the yields of fresh and dry mass in the second cut can be higher than the yields in the first cut when the weather conditions are optimal during cultivation.

The essential oil content increased with the application of fertilizers, compared to that in control, but only in the first cut (Table 3 ). The plants grown using the mineral fertilizer $\left(0.94 \mathrm{~mL} 100 \mathrm{~g}^{-1}\right)$ had a significantly higher essential oil content compared to those grown without fertilizers (control) $\left(0.71 \mathrm{~mL} 100 \mathrm{~g}^{-1}\right)$. Although there were no significant differences, the plants grown with the organomineral and organic fertilizers $(0.84$ and 0.83 $\mathrm{mL} 100 \mathrm{~g}^{-1}$, respectively) had a higher essential oil content compared to those grown without fertilizers. Results of the contents of essential oils showed certain differences between the cuts although there was no significant difference. The essential oil content in the first cut was

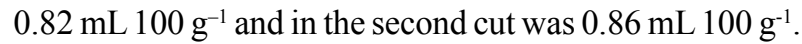

Our results suggested that the application of all fertilizer types significantly increased the content of essential oils in the first cut. This was probably because fertilizers led to an increase in the availability of nutrients in the soil that the plants needed for optimal growth and development. Our explanation is supported by the fact that mineral fertilizers, which have the highest content of readily available nutrients, had the greatest effect on the increase in the content of essential oils. These results agreed with those obtained by other researchers (Esetlili et al., 2016; Hassan et al., 2015; Kandil et al., 2009; Silva et al., 2017). Although no significant differences in essential oil content were found between the different cuttings, the results suggested that the average essential oil content in the second cut was higher than that in the first cut, probably due to the lack of precipitation. Omidbaigi, Hassani, and Sefidkon (2003) had reported that the essential oil content in basil increased when the precipitation decreased; the oil content increased from $1.12 \%$ to $1.26 \%$ as the plant water deficit increased (till $70 \%$ of field capacity). In our experiments, the plants experienced 3.2 times lesser precipitation after the first cut.

The total phenolic content, total flavonoid content, and antioxidant capacity were not significantly affected by different fertilizers (Table 3 ). However, significant differences in these parameters were recorded depending on the time of cutting. Higher values for these parameters were recorded in the second cutting. Specifically, basil in the second cut had $12.8 \%$ more phenol, $18.0 \%$ more flavonoids, and $25.67 \%$ more antioxidants compared to basil in the first cut.

The contents of bioactive compounds and the antioxidant capacity of basil were not affected by the type of fertilizer used. The application of fertilizers did not affect the total phenol content, which was in contrast to the study by Teliban et al. (2020). They examined the effects of four types of fertilizers (biosolids, microorganisms, organic fertilizers, and mineral fertilizers) on bioactive compounds and the antioxidant capacity of basil, and found that the content of bioactive compounds and the value of the antioxidant capacity in basil increased in all the treatments. Our results suggested that the application of fertilizers did not affect the contents of bioactive compounds and the antioxidant capacity of basil. This was probably because basil was grown at temperatures lower than the required temperature, and the weather conditions had a greater impact relative to the effects of fertilizers on the content of bioactive compounds. On the other hand, 
the contents of bioactive compounds (total phenol and flavonoid) and antioxidant capacity were significantly higher in basil during the second cut. The finding was consistent with those of Gavrić et al. (2018b), where it was reported that the content of total phenol ranged from 29.51 $\mathrm{mg} \mathrm{GAE} \mathrm{g}^{-1}$ (first cut) to $36.68 \mathrm{mg} \mathrm{GAE} \mathrm{g}^{-1}$ (first cut). The production of total phenol in a plant is largely dependent on many environmental factors (Burdina; Priss, 2016; Gavrić et al., 2018a; Rymen et al., 2007), and its concentration in the plant increases during abiotic stress (Gavrić et al., 2020; Mbaveng; Zhao; Kuete, 2014). Thus, the main factors that might have affected the additional synthesis of phenol in the second cut were weather conditions. Basil is a thermophilic plant and requires high temperatures for optimal growth; however, sub-optimal temperatures were recorded a month before the second cut, causing abiotic stress, which was a signal for the plant to synthesize greater quantities of phenols to protect itself. Additionally, during this period, stress was caused by a lack of precipitation which was 3.2 times lesser than that in the previous period.

From Table 4, it can be seen that there was a positive correlation between some of the parameters. The data showed a strong correlation between fresh and dry mass $(r=0.698)$, the total phenol content and antioxidant capacity $(\mathrm{r}=0.806)$, and the total flavonoid content and antioxidant capacity $(r=0.765)$. Correlation coefficients also indicated that the highest negative correlations were between total flavonoids and the yields of fresh mass $(r=-0.473)$ and dry mass $(r=-0.471)$ and between the antioxidant capacity and dry mass $(\mathrm{r}=-0.496)$.

In our study, the different times of cutting affected all the research parameters. However, different fertilizer types did not affect the contents of the bioactive compounds and the antioxidant capacity. The doses of fertilizers applied were based on the experience of the farmers However, applying a fixed dose of fertilizer was a limitation of this study because it did not give results for the effect of different fertilizer doses on the quality of basil. To eliminate these limitations, future researchers should consider the potential impact of different fertilizer types and doses more carefully, for example, on the composition of essential oils and phenols. This is because the healing and aromatic qualities of basil and its price depend on these chemical compositions. However, despite this limitation, our research has shown that some of these benefits can be used in practice. A higher yield

Table 3: Effect of fertilization on the content of essential oils, total phenolics, total flavonoids, and antioxidant capacity.

\begin{tabular}{|c|c|c|c|c|c|}
\hline Cuts & Fertilizer & $\begin{array}{l}\text { Essential oil } \\
\mathrm{mL} 100 \mathrm{~g}^{-1}\end{array}$ & $\begin{array}{c}\text { Total phenolics } \\
\mathrm{mg} \mathrm{GAE} \mathrm{g}^{-1}\end{array}$ & $\begin{array}{c}\text { Total flavonoids } \\
\text { mg CAE g }\end{array}$ & $\begin{array}{c}\text { Antioxidant capacity } \\
\qquad \mathrm{M} \mathrm{Fe}^{2+} \mathrm{g}^{-1}\end{array}$ \\
\hline \multirow{5}{*}{$\begin{array}{l}\text { First } \\
\text { cut }\end{array}$} & Mineral & $0.94 \pm 0.09^{\mathrm{a}}$ & $42.63 \pm 2.52^{\mathrm{ns}}$ & $35.71 \pm 5.54^{\text {ns }}$ & $49.64 \pm 8.26^{\mathrm{ns}}$ \\
\hline & Organic & $0.84 \pm 0.07^{a b}$ & $42.63 \pm 4.42^{\mathrm{ns}}$ & $36.10 \pm 6.30^{\mathrm{ns}}$ & $43.71 \pm 7.12^{\mathrm{ns}}$ \\
\hline & Organo-mineral & $0.83 \pm 0.13^{\mathrm{ab}}$ & $41.13 \pm 4.59^{n s}$ & $34.49 \pm 2.29^{\text {ns }}$ & $44.31 \pm 14.00^{\mathrm{ns}}$ \\
\hline & Control & $0.71 \pm 0.03^{b}$ & $40.98 \pm 2.52^{\mathrm{ns}}$ & $35.86 \pm 1.48^{\mathrm{ns}}$ & $43.68 \pm 3.20^{\mathrm{ns}}$ \\
\hline & Average & $0.83 \pm 0.12^{\mathrm{ns}}$ & $41.84 \pm 3.65^{b}$ & $35.54 \pm 4.12^{b}$ & $45.45 \pm 8.74^{b}$ \\
\hline \multirow{5}{*}{$\begin{array}{l}\text { Second } \\
\text { cut }\end{array}$} & Mineral & $0.86 \pm 0.10^{\text {ns }}$ & $43.82 \pm 8.42^{\mathrm{ns}}$ & $38.34 \pm 4.45^{\text {ns }}$ & $54.16 \pm 15.04^{\mathrm{ns}}$ \\
\hline & Organic & $0.90 \pm 0.12^{\mathrm{ns}}$ & $48.52 \pm 2.37^{\mathrm{ns}}$ & $44.57 \pm 4.57^{\mathrm{ns}}$ & $61.96 \pm 1.11^{\mathrm{ns}}$ \\
\hline & Organo-mineral & $0.88 \pm 0.11^{\text {ns }}$ & $50.14 \pm 3.24^{\mathrm{ns}}$ & $44.73 \pm 1.78^{\mathrm{ns}}$ & $63.09 \pm 7.18^{\text {ns }}$ \\
\hline & Control & $0.87 \pm 0.07^{\mathrm{ns}}$ & $49.54 \pm 5.20^{\mathrm{ns}}$ & $45.75 \pm 4.12^{\mathrm{ns}}$ & $61.15 \pm 10.03^{n s}$ \\
\hline & Average & $0.87 \pm 0.09^{\text {ns }}$ & $48.00 \pm 5.20^{\mathrm{a}}$ & $43.35 \pm 4.83^{\mathrm{a}}$ & $61.15 \pm 10.10^{a}$ \\
\hline \multirow{5}{*}{ Average } & Mineral & $0.90 \pm 0.09^{\text {ns }}$ & $43.22 \pm 6.26^{\mathrm{ns}}$ & $37.02 \pm 5.28^{\text {ns }}$ & $51.90 \pm 11.49^{\text {ns }}$ \\
\hline & Organic & $0.87 \pm 0.10^{\text {ns }}$ & $45.57 \pm 4.34^{\mathrm{ns}}$ & $40.33 \pm 6.88^{\text {ns }}$ & $51.53 \pm 10.99^{n s}$ \\
\hline & Organo-mineral & $0.85 \pm 0.12^{\mathrm{ns}}$ & $45.64 \pm 6.06^{\mathrm{ns}}$ & $39.61 \pm 0.79^{\text {ns }}$ & $53.70 \pm 14.42^{\mathrm{ns}}$ \\
\hline & Control & $0.79 \pm 0.10^{\text {ns }}$ & $45.26 \pm 5.21^{\mathrm{ns}}$ & $40.81 \pm 6.09^{n s}$ & $56.21 \pm 13.82^{\text {ns }}$ \\
\hline & Average & $0.85 \pm 0.11$ & $44.92 \pm 5.38$ & $39.44 \pm 5.91$ & $53.30 \pm 12.29$ \\
\hline
\end{tabular}

${ }^{a}$ and $^{\mathrm{b}}$ - Statistically significant difference at the 0.05 level.

ns - Statistically not significant difference at the 0.05 level. 
Table 4: The correlation between the measured traits.

\begin{tabular}{ccccccc}
\hline & $\begin{array}{c}\text { Fresh mass } \\
\text { yield }\end{array}$ & $\begin{array}{c}\text { Dry mass } \\
\text { yield }\end{array}$ & $\begin{array}{c}\text { Essential } \\
\text { oil }\end{array}$ & $\begin{array}{c}\text { Total } \\
\text { phenolics }\end{array}$ & $\begin{array}{c}\text { Total } \\
\text { flavonoids }\end{array}$ & $\begin{array}{c}\text { Antioxidant } \\
\text { capacity }\end{array}$ \\
\hline Fresh mass yield & 1 & & & & & \\
Dry mass yield & $0.698^{*}$ & 1 & & & & \\
Essential oil & 0.165 & 0.174 & 1 & & & \\
Total phenolics & -0.336 & -0.339 & 0.362 & 1 & 1 & 1 \\
Total flavonoids & $-0.473^{*}$ & $-0.471^{*}$ & 0.253 & $0.849^{*}$ & $0.765^{*}$ & 1 \\
Antioxidant capacity & -0.346 & $-0.496^{*}$ & 0.331 & $0.806^{*}$ & & \\
\hline
\end{tabular}

* Correlation is significant at the 0.01 level (2-tailed).

and an appropriate quality of basil can be achieved by using different types of fertilizers, which is especially interesting for organomineral fertilizers since they are a more recent development. Organomineral fertilizers can be used as a nutrient source in basil crop production in areas where the use of mineral and organic fertilizers is limited.

\section{CONCLUSIONS}

Our results showed that the yield and content of essential oils in basil increased with the use of fertilizers. The highest yield and oil content were recorded in basil cultivated using mineral fertilizers. However, the results also showed that the application of organomineral fertilizers was effective and that they can be an alternative to mineral and organic fertilizers. Moreover, the bioactive compounds and the antioxidant capacity of basil grown using organomineral fertilizers did not differ significantly from those grown using other types of fertilizers.

\section{REFERENCES}

AMAROWICZ, R. et al. Effect of $\mathrm{N}$ fertilization on the content of phenolic compounds in jerusalem artichoke (Helianthus tuberosus L.) tubers and their antioxidant capacity. Agronomy, 10(8):1215, 2020.

BENZIE, I.; STRAIN, J. The ferric reducing ability of plasma (FRAP) as a measure of "Antioxidan power": The FRAP assay analytical biochemistry. Analytical Biochemistry, 239(1):70-76, 1996.

BUCKTOWAR, K.; BUCKTOWAR, M.; DEVI BHOLOA, L. A review on sweet basil seeds: Ocimum basilicum. World Journal of Pharmacy and Pharmaceutical Sciences, 5(12):554567, 2016.
BURDINA, I.; PRISS, O. Effect of the substrate composition on yield and quality of basil (Ocimum basilicum L.). Journal of Horticultural Research, 24(2):109-118, 2016.

CLEVENGER, J. F. Apparatus for the determination of volatile oil. The Journal of the American Pharmaceutical Association (1912), 17(4):345-349, 1928.

CORRADO, G. et al. Successive harvests affect yield, quality and metabolic profile of sweet basil (Ocimum basilicum L.). Agronomy, 10(6):830, 2020.

CORRÊA, J. C. et al. Organic, organomineral, and mineral fertilizers with urease and nitrification inhibitors for wheat and corn under no-tillage. Pesquisa Agropecuaria Brasileira, 51(8):916-924, 2016.

DEL VALLE, J. C. et al. UV radiation increases phenolic compound protection but decreases reproduction in Silene littorea. Plos One, 15(6):e0231611, 2020.

DEEKS, L. K. et al. A new sludge-derived organo-mineral fertilizer gives similar crop yields as conventional fertilizers. Agronomy for Sustainable Development, 33(3):539-549, 2013.

DZIDA, K. et al. Effect of potassium fertilization on yield, growth and chemical composition of basil herb. Acta Scientiarum Polonorum Hortorum Cultus, 17(6):135-145, 2018.

EGNÉR, H.; RIEHM, H.; DOMINGO, W. R. Untersuchungen über die chemische bodenanalyse als grundlage für die beurteilung des nährstoffzustandes der böden. II. Chemische extraktionsmethoden zur phosphor-und kaliumbestimmung. Kungliga Lantbrukshögskolans Annaler, 26:199-215, 1960.

ESETLILI, B. Ç. et al. Sweet basil (Ocimum basilicum L.) and potassium fertilization. Journal of Plant Nutrition, 39(1):35-44, 2016. 
FEDERALNI HIDROMETEOROLOŠKI ZAVOD - FHMZ. Analiza godine. 2019. Available in: <https://www.fhmzbih.gov.ba/ latinica/index.php>. Access in: January, 16, 2021.

GAVRIĆ, T. et al. Influence of meteorological parameters on the yield and chemical composition of common buckwheat (Fagopyrum esculentum Moench). The Journal Agriculture and Forestry, 64(4):113-120, $2018 \mathrm{a}$.

GAVRIĆ, T. et al. Yield and contents of some bioactive components of basil (Ocimum basilicum L.) depending on time of cutting. Studia Universitatis Vasile Goldis Arad, Seria Stiintele Vietii, 28(4):192-197, 2018b.

GAVRIĆ, T. et al. Chemical composition and total phenols content of tartary buckwheat (Fagopyrum tataricum Gaertn) grown in different vegetation seasons. IFMBE Proceedings, 78:59-68, 2020.

KAZIMIERCZAK, R. et al. The effect of different fertilization regimes on yield, selected nutrients, and bioactive compounds profiles of onion. Agronomy, 11(5):883, 2021.

HAN, S. H. et al. The effects of organic manure and chemical fertilizer on the growth and nutrient concentrations of yellow poplar (Liriodendron tulipifera Lin.) in a nursery system. Forest Science and Technology, 12(3):137-143, 2016.

HASSAN, M. R. A. et al. Effect of NPK and bio-fertilizers rates on the vegetative growth and oil yield of Ocimum basillicum L. plants. Alexandria Science Exchange Journal, 36:5872, 2015.

HASSANAIN, M. A.; ABDELLA, E. M. Response of sweet basil plant, (Ocimum basilicum L.) to different nitrogen source. Journal of Agriculture and Environmental Sciences Alexandria University Egypt, 2(2):4-13, 2003.

HIRZEL, J. et al. Evolution of nutrients and soil chemical properties of seven organic fertilizers in two contrasting soils under controlled conditions. Chilean Journal of Agricultural and Animal Sciences, 34(2):77-88, 2018.

IPSILANDIS, C. G. et al. Fertilizer application in basil (Ocimum basilicum) cultivation in Greece. Medicinal and Aromatic Plants, 9(2):345, 2020.

ISO 10390. Soil Quality - Determination of pH. International Organization for Standardization, Geneve, Switzerland, p.1-5, 1994.

ISO 14235. Soil Quality-Determination of organic carbon by sulfochromic oxidation. International Organization for Standardization, Geneve, Switzerland, p. 1-5, 1998.
LIMA, J. C. et al. Macronutrient fertilizers on basil growth and yield. Comunicata Scientiae, 11:e3200, 2020.

KANDIL, M. A. M. et al. Herbal and essential oil yield of Genovese basil (Ocimum basilicum L.) grown with mineral and organic fertilizer sources in Egypt. Journal Für Kulturpflanzen, 61(12):443-449, 2009.

KASOTE, D. M. et al. Significance of antioxidant potential of plants and its relevance to therapeutic applications. International Journal of Biological Sciences, 11(8):982-991, 2015.

MAJKOWSKA-GADOMSKA, J. et al. Yield and nutritional value of basil grown in a greenhouse. Acta Agrophysica, 24(3):455464, 2017.

MBAVENG, A. T.; ZHAO, Q.; KUETE, V. Harmful and protective effects of phenolic compounds from African medicinal plants. In: KUETE, V. Toxicological Survey of African Medicinal Plants, 1 ed. Elsevier, 2014. p.577-609.

SHAHRAJABIAN, M. H.; WENLI SUN, W.; CHENG, Q. Chemical components and pharmacological benefits of basil (Ocimum basilicum): A review. International Journal of Food Properties, 23(1):1961-1970, 2020.

OJO, J. A.; OLOWOAKE, A. A.; OBEMBE, A. Efficacy of organomineral fertilizer and un-amended compost on the growth and yield of watermelon (Citrullus lanatus Thumb) in Ilorin Southern Guinea Savanna zone of Nigeria. International Journal of Recycling of Organic Waste in Agriculture, 3(4):121-125, 2014.

OMIDBAIGI, R.; HASSANI, A.; SEFIDKON, F. Essential oil content and composition of sweet basil (Ocimum basilicum) at different irrigation regimes. Journal of Essential OilBearing Plants, 6(2):104-108, 2003.

PORTILLA, N. et al. Soil amendment with biosolids and inorganic fertilizers: Effects on biochemical properties and oxidative stress in basil (Ocimum basilicum L.). Agronomy, 10(8):1117, 2020.

RYMEN, B. et al. Cold nights impair leaf growth and cell cycle progression in maize through transcriptional changes of cell cycle genes. Plant Physiology, 143(3):1429-1438, 2007.

SCAGEL, C. F.; LEE, J. Phenolic composition of basil plants is differentially altered by plant nutrient status and inoculation with mycorrhizal fungi. HortScience, 47(5):660671, 2012.

SHARMA, A. et al. Response of phenylpropanoid pathway and the role of polyphenols in plants under abiotic stress. Molecules, 24(13):2452, 2019. 
SILVA, S. M. et al. Organo-mineral fertilization effects on biomass and essential oil of lavender (Lavandula dentata L.). Industrial Crops and Products, 103:133140, 2017.

SODRÉ, A. C. B. et al. Organic and mineral fertilization and chemical composition of lemon balm (Melissa officinalis) essential oil. Brazilian Journal of Pharmacognosy, 22(1):40-44, 2011.

STANOJKOVIĆ-ŠEBIĆ, A. et al. Effect of indigenous pseudomonas chlororaphis strains on morphological and main chemical growth parameters of basil (Ocimum basilicum L.). Ratarstvo i Povrtarstvo, 54(2):42-47, 2017.
TELIBAN, G. C. et al. Biochemical, physiological and yield characteristics of red basil as affected by cultivar and fertilization. Agriculture, 10(2):48, 2020.

TIMSINA, J. Can organic sources of nutrients increase crop yields to meet global food demand? Agronomy, 8(10):214, 2018.

TSASI, G. et al. The effect of harvesting on the composition of essential oils from five varieties of Ocimum basilicum L. cultivated in the Island of Kefalonia, Greece. Plants, 6(3):41, 2017.

ZAREEN, A. et al. Screening of antibacterial potential of siam queen, holy basil and Italian basil essential oils. Journal of Medicinal Plants Studies, 2(2):63-68, 2014. 